\title{
PENGARUH MODEL PEMBELAJARAN VAK (VISUAL, AUDITORY, KINESTETIK) TERHADAP KEMAMPUAN MENULIS TEKS EKSPOSISI OLEH SISWA KELAS X SMK SANDHY PUTRA 2 MEDAN TAHUN PEMBELAJARAN 2018/2019
}

\author{
Wahdini (wahdini.0215@gmail.com) \\ Frinawaty L. Barus (frinawatybarus@unimed.ac.id) \\ Universitas Negeri Medan
}

\begin{abstract}
ABSTRAK
Penelitian ini bertujuan untuk mengetahui adanya pengaruh model pembelajaran VAK (Visual, Auditory, Kinestetik) terhadap kemampuan siswa dalam menulis teks eksposisi siswa kelas X SMK Sandhy Putra 2 Medan. Sampel dalam penelitian ini adalah siswa kelas X TKJ 3 dan X TKJ 4 yang berjumlah 60 orang. Instrumen penelitian yang digunakan adalah tes kinerja siswa. Metode penelitian yang digunakan adalah quasi eksperimen dengan model two-groups posttest design. Berdasarkan analisis data diperoleh bahwa nilai ratarata pada kelas eksperimen 84,5 sedangkan di kelas kontrol memiliki nilai rata-rata 63,16. Penggunaan video yang memicu keaktifan dan meningkatkan minat siswa dalam belajar. Aspek penilaian tulisan siswa dinilai dari empat aspek yaitu struktur, ciri kebahasaan, kosakata, dan mekanik. Berdasarkan uji persyaratan analisis data melalui tes normalitas dan homogenitas maka diperoleh data penelitian berdistribusi normal dengan perhitungan $\mathrm{L}_{\text {hitung }}<\mathrm{L}_{\text {tabel }}$ atau $0,13<0,16$ dan sampel berdistribusi homogen dengan perhitungan dan $\mathrm{X}^{2}$ hitung $<\mathrm{X}^{2}$ tabel yaitu $2,67<42,6$. Berdasarkan uji hipotesis diperoleh bahwa, $t_{0}$ yang diperoleh lebih besar dari $t_{\text {tabel }}$ yaitu 12,62 > 1,67, maka hipotesis alteratif $\left(\mathrm{H}_{\mathrm{a}}\right)$ diterima. Jadi, dapat disimpulkan bahwa ada pengaruh model pembelajaran VAK (Visual, Auditory, Kinestetik) terhadap kemampuan siswa menulis teks eksposisi oleh siswa kelas X SMK Sandhy Putra 2 Medan Tahun Pembelajaran $2018 / 2019$.
\end{abstract}

Kata Kunci: Teks eksposisi, model VAK(Visual, Auditory, Kinestetik)

\section{PENDAHULUAN}

Pembelajaran bahasa Indonesia di sekolah adalah pembelajaran berbasis teks. Pada jenjang SMA kelas X salah satu jenis teks yang dipelajari adalah teks eksposisi. Pembelajaran teks eksposisi terdapat dalam KD 4.4, yaitu mengontruksikan teks eksposisi dengan memerhatikan isi (permasalahan, argumen, pengetahuan, dan rekomendasi), struktur, dan ciri kebahasaan. Teks eksposisi merupakan teks yang berisi pemaparan, penjelasan, pendeskripsian mengenai satu hal yang diperinci secara spesifik guna mendapatkan pengetahuan dan informasi yang up to date dengan sumber data yang objektif misalnya fakta, 
contoh-contoh, gagasan-gagasan penulisnya, ataupun pendapat-pendapat para ahli. Mahsun (2014:31), menyatakan bahwa teks eksposisi merupakan paparan gagasan atau usulan mengenai sesuatu yang bersifat pribadi. Oleh sebab itu, siswa diharapkan mampu untuk menulis teks eksposisi dengan baik sesuai dengan tujuan pembelajaran yaitu mengontruksi teks eksposisi dengan memperhatikan struktur dan ciri kebahasaan.

Mengajar diartikan sebagai usaha mengorganisasi lingkungan sehingga menciptakan kondisi belajar bagi siswa. Secara modern, konsep mengajar merupakan suatu perbuatan yang memerlukan tanggung jawab moral yang cukup berat. Guru berperan sebagai kreator proses belajar mengajar, yakni berperan sebagai orang yang mampu menciptakan kondisi pembelajaran yang baik, menarik, dan berdaya guna. Dengan demikian, dapat ditegaskan bahwa orientasi mengajar dalam konteks belajar mengajar pembelajaran digunakan untuk pengembangan aktivitas siswa dalam belajar.Menurut Arends dalam Ngalimun (2014:7), model pembelajaran adalah suatu perencanaan atau suatu pola yang digunakan sebagai pedoman dalam merencanakan pembelajaran di kelas atau pembelajaran dalam toturial dan untuk menentukan perangkat-perangkat pembelajaran termasuk di dalamnya buku-buku, film, komputer, kurikulum, dan lain sebagainya.

Model pembelajaran VAK (Visual, Auditory, Kinestetik) yang merupakan model pembelajaran yang mengoptimalkan ketiga modalitas belajar yaitu Visual, Auditory, dan Kinestetik untuk menjadikan peserta didik merasa nyaman dan memaksimalkan penerimaan materi secara merata dan untuk meningkatkan hasil belajar peserta didik.Shoimin (2016:227) menyebutkan "Pemanfaatan dan pengembangan potensi siswa dalam proses belajar mengajar dengan memerhatikan kebutuhan dan gaya belajar siswa hal ini, menyangkut dengan bagian visual (menggunakan media dua dimensi seperti grafik, gambar, chart, model dan sebagainya), Auditory lebih mengutamakan pendengaran atau semacam yang diucapkan, dan kinestetik dengan melakukan kegiatan tertentu”.

Berdasarkan hasil penelitian yang dilakukan oleh Kurnia (2015) menyebutkan bahwa siswa masih merasa kesulitan untuk mengembangkan suatu gagasan atau ide menjadi karangan yang baik. Keterbatasan siswa dalam 
menguasai kosakata juga dapat menyebabkan siswa sulit untuk mengembangkan gagasan atau ide ke dalam bentuk tulisan. Hal ini yang menjadi faktor kemampuan menulis teks eksposisi oleh siswa masih rendah.

Rendahnya kemampuan siswa dalam menulis teks eksposisi menunjukkan bahwa siswa belum menguasai pembelajaran teks eksposisi dengan baik. Melalui model pembelajaran siswa diajak untuk lebih berperan aktif dan mencoba untuk meningkatkan minat dalam mengikuti proses belajar mengajar. Seperti penelitian yang telah dilakukan oleh Fathonah (2016) diperoleh hasil bahwa terlihat adanya peningkatan motivasi siswa dalam kegiatan pembelajaran menulis puisi melalui VAK (Visual, Auditori, Kinestetik). Hal ini bisa dilihat dari beberapa tahap yaitu ketuntasan hasil belajar siswa pada prasiklus, belum semua siswa mencapai ketuntasan hasil belajar. Selanjutnya, pada siklus I sejumlah 17 siswa atau 54,83\% sudah mencapai ketuntasan hasil belajar atau memenuhi syarat KKM. Pada siklus II, sebanyak 28 siswa atau 90,32\% sudah dinyatakan tuntas atau memenuhi syarat KKM. Pencapaian siklus II tersebut sudah memenuhi indikator keberhasilan penelitian yang telah ditetapkan, yakni ketuntasan belajar siswa lebih dari $75 \%$. Dengan demikian, melalui model VAK (Visual, Audiotory, Kinestetik) dapat meningkatkan keterampilan siswa menulis puisi.

Kemudian, penelitian yang telah dilakukan oleh Setiawan (2015), menunjukkan bahwa hasil belajar siswa dalam memahami materi listrik dinamis sebelum mendapat tindakan menunjukkan nilai rata-rata 41,9\%. Sedangkan setelah mendapat tindakan menunjukkan nilai rata-rata 91,41\%. Hal ini membuktikan bahwa hasil belajar siswa bisa ditingkatkan melalui penggunaan model VAK (Visual, Auditory, Kinestetik).

Beberapa masalah di atas menjadi dasar penulis untuk melakukan penelitian dengan judul "Pengaruh Model Pembelajaran VAK (Visual, Auditory, Kinestetik) Terhadap Kemampuan Menulis Teks Eksposisi Oleh Siswa Kelas X SMK Sandhy Putra 2 Medan Tahun Pembelajaran 2018/2019.” Penelitian ini bertujuan untuk mengetahui adanya pengaruh yang signifikan terhadap kemampuan siswa dalam menulis teks eksposisi. 


\section{METODE PENELITIAN}

Penelitian ini dilakukan di SMK Sandhy Putra 2 Medan yang berlokasi di Jl. Halat No. 68, Medan. Penelitian ini merupakan penelitian quasi eksperimen dengan model two-group posttest design, yaitu eksperimen yang dilaksanakan pada dua kelompok, kelompok pertama dan kedua diberi perlakuan, hanya saja kelompok pertama disebut kelas eksperimen dan kelompok kedua disebut kelas kontrol. Sugiyono (2017:112) mengungkapkan bahwa "Model two-group posttest design adalah metode eksperimen yang dilakukan pada dua kelompok yang dipilih secara acak, kelompok pertama diberi perlakuan dan kelompok yang lain tidak".

Instrumen dalam penelitian ini adalah berupa tes penugasan untuk kerja dalam bentuk tes kemampuan menulis teks eksposisi. Tes ini dilakukan dengan dengan post-test untuk mendapatkan data kemampuan menulis teks eksposisi setelah diadakan perlakuan dengan membandingkan hasil dari kelas kontrol.Dalam penelitian ini data yang digunakan adalah data kuantitatif, dikatakan sebagai data kuantitatif karena gambaran datanya menggunakan ukuran, jumlah, atau frekuensi yaitu nilai kemampuan siswa.

Setelah semua terkumpul, selanjutnya penulismenganalisis data dengan cara mencari nilai rata-rata atau mean digunakan rumus, mencari standar deviasi dengan rumus dan mencari standar error. Selain itu, dilakukan uji persyaratan analisis data dengan cara uji normalitas (membuktikan data berdistribusi normal), uji homogenitas (membuktikan sampel berdistribusi sama) dan uji hipotesis (membuktikan hipotesis alternatif diterima/ditolak).

\section{HASIL PENELITIAN DAN PEMBAHASAN}

\section{A. Hasil Penelitian}

Kemampuan siswa kelas X SMK Sandhy Putra 2 Medan tahun pembelajaran 2018/2019 dalam pembelajaran menulis teks eksposisi dengan menggunakan model VAK (Visual, Auditory, Kinestetik) di kelas eksperimen tergolong baik. Hal ini dapat dilihat dari pemerolehan nilai rata-rata sebesar 84.5 yang berarti termasuk kategori baik dan sudah mencapai nilai KKM yang sudah ditentukan yaitu 7.50. seperti yang terlihat pada tabel berikut ini. 
Tabel 1

Rentang Skor dan Kategori Penilaian Kemampuan Menulis Teks Eksposisi dengan Menggunakan Model VAK (Visual, Auditory, Kinestetik)

\begin{tabular}{c|c|c|c}
\hline RENTANG & FREKUENSI & F. RELATIF & KATEGORI \\
\hline $85-100$ & 20 & $66,67 \%$ & Sangat Baik \\
\hline $70-84$ & 10 & $33,33 \%$ & Baik \\
\hline $55-69$ & 0 & 0 & Cukup \\
\hline $40-54$ & 0 & 0 & Kurang \\
\hline $0-39$ & 0 & 0 & Sangat Kurang \\
\hline & 30 & $100 \%$ & \\
\hline
\end{tabular}

Berdasarkan tabel pengkategorian di atas, dapat diketahui bahwa kemampuan menulis teks eksposisi dengan menggunakan model VAK (Visual, Auditory, Kinestetik) di kelas eksperimen termasuk dalam kategori sangat baik sebanyak 20 orang $(66,67 \%)$, kategori baik sebanyak 10 orang $(33,33 \%)$, dan kategori cukup, kategori kurang, serta kategori sangat kurang tidak ada.

Kemampuan siswa kelas X SMK Sandhy Putra 2 Medan tahun pembelajaran 2018/2019 dalam pembelajaran menulis teks eksposisi dengan menggunakan model Cooperative Learning di kelas kontrol tergolong rendah. Hal tersebut dapat dilihat dari pemerolehan nilai rata-rata yang mencapai 63,18 yang berarti termasuk dalam kategori cukup dan masih berada di bawah KKM yang sudah ditentukan yaitu 75,0.

Tabel 2

Rentang Skor dan Kategori Penilaian Kemampuan Menulis Teks Eksposisi dengan Menggunakan Model Cooperative Learning

\begin{tabular}{c|c|c|c}
\hline RENTANG & FREKUENSI & F. RELATIF & KATEGORI \\
\hline $86-100$ & 0 & $0,00 \%$ & Sangat Baik \\
\hline $70-84$ & 11 & $36,66 \%$ & Baik \\
\hline $55-69$ & 14 & $46,67 \%$ & Cukup \\
\hline $40-54$ & 5 & $16,67 \%$ & Kurang \\
\hline $0-39$ & 0 & 0 & Sangat Kurang \\
\hline & 30 & $100 \%$ & \\
\hline
\end{tabular}


Berdasarkan tabel di atas, dapat diketahui bahwa kemampuan menulis teks eksposisi dengan menggunakan model cooperative learning di kelas kontrol termasuk dalam kategori baik sebanyak 11 orang $(36,66 \%)$, kategori cukup sebanyak 14 orang (46,67\%), kategori kurang sebanyak 5 orang $(16,67 \%)$, dan kategori sangat baik serta kategori sangat kurang tidak ada.

Penganalisisan data dilakukan dengan menggunakan statistik komparasi yaitu dengan mengguakan uji " $\mathrm{t}$ ". Analisis ini dapat digunakan dengan syarat bahwa data setiap variabel yang diteliti harus berdistribusi normal dan bersifat homogen. Oleh karena itu, hal yang pertama dilakukan ialah pengujian normalitas dan homogenitas data. Pengujian normalitas data dapat dilakukan dengan menggunakan uji liliefors. Syarat normal yang harus dipenuhi adalah $\mathrm{L}_{\mathrm{hitung}}>$ Lpada taraf signifikansi $\alpha=0.05$.

Harga L yang paling besar diantara harga-harga mutlak selisih tersebut $\mathrm{L}_{\text {hitung }}=0.13$, dari tabel kritis $\mathrm{L}$ untuk uji Liliefors dengan $\mathrm{N}=30$ dan taraf nyata $\alpha$ $=0.05$ didapat $\mathrm{L}_{\text {tabel }}=0.16$. Setelah dibandingkan ternyata Lhitung $<$ Ltabel atau $0.13<0.16$. Maka dapat disimpulkan bahwa data variabel $\mathrm{X}_{1}$ berdistribusi normal. harga $\mathrm{L}$ yang paling besar diantara harga-harga mutlak selisih tersebut $\mathrm{L}_{\text {hitung }}=0.126$, dari tabel kritis $\mathrm{L}$ untuk uji Liliefors dengan $\mathrm{N}=30$ dan taraf nyata $\alpha=0.05$ didapat $\mathrm{L}_{\text {tabel }}=0.161$. Setelah dibandingkan ternyata Lhitung < Ltabel atau $0.128<0.161$. Maka dapat disimpulkan bahwa data variabel $\mathrm{X}_{2}$ berdistribusi normal. Dalam perhtungan uji homogenitas menggunakan perhitungan $\mathrm{X}^{2}$ (Chi Kuadrat) hitung sebesar 0.66. Harga $X^{2}$ tabel pada taraf kepercayaan 95\% dengan dk 29 adalah 42.6. Ternyata $X^{2}$ hitung $<X^{2}$ tabel yaitu $2.67<42.6$. Hal ini membuktikan bahwa varians populasi adalah homogen.Kemudian, dilakukan uji hipotesis.

\section{B. Pembahasan}

1. Kemampuan menulis teks eksposisi dengan menggunakan model VAK (Visual, Auditory, Kinestetik) oleh siswa X SMK Sandhy Putra 2 Medan Tahun Pembelajaran 2018/2019

Kegiatan pembelajaran diawali dengan memacu semangat siswa agar mampu mengikuti pembelajaran dengan baik dan memiliki kosentrasi yang 
tinggi. Kemudian, guru menjelaskan tujuan pembelajaran yang harus dicapai. Selanjutnya, guru melaksanakan proses pembelajaran dengan menggunakan model pembelajaran VAK (Visual, Auditory, Kinestetik) dengan menerapkan pendekatan saintifik dalam pembelajaran.Model VAK merupakan model yang mengoptimalkan ketiga gaya belajar yaitu dengan melihat, mendengar, dan bergerak untuk menjadikan peserta didik merasa nyaman dan menjadikan kesuksesan bagi pembelajarnya untuk menguraikan cara-cara baru dalam memudahkan proses belajar mengajar, lewat pemaduan unsur seni dan pencapaian-pencapaian yang terarah. Memaksimalkan penerimaan materi secara merata dan untuk meningkatkan hasil belajar peserta didik.

Guru menampilkan sebuah video pembelajaran mengenai teks eksposisi yang memuat struktur dan ciri kebahasaan. Siswa mengamati dan menuliskan point-point penting dari video tersebut. Kemudian, siswa mulai bertanya mengenai suatu hal yang belum dipahami. Setelahnya, guru kembali memberikan pertanyaan kepada siswa dan mengamati bagaimana siswa menanggapi masalah yang dihadapi. Guru memberikan satu contoh mengenai teks eksposisi berdasarkan buku panduan bahasa Indonesia SMK kelas X. Setelah siswa cukup memahami tentang konsep dasar, struktur, dan ciri kebahasaan teks eksposisi, kemudian dilanjutkan dengan menampilkan sebuah video mengenai "banjir" yang akan menjadi tema dalam menulis sebuah teks eksposisi yang utuh.

Secara umum, struktur teks eksposisi yang ditulis oleh siswa sudah ampu menggambarkan tesis, argumentasi, penegasan ulang (rekomendasi). Mengenai ciri kebahasaan, siswa mampu mengembangkan paragraf dengan memanfaatkan ciri kebahasaan seperti mengomentari sebuah pernyataan, memberi kesan menggunakan pernyataan persuasif, menyediakan fakta dalam menguatkan argumentasi sehingga menyajikan tulisan teks eksposisi dengan baik.

Penjelasan mengenai kosakata terlihat dari pengembangan paragraf yang siswa tulis berdasarkan point-point penting dari video yang ditampilkan dalam proses pembelajaran. Siswa menyusun sedemikian 
rupa, sehingga informasi yang disampaikan tersaji dengan baik. Hal ini terlihat dari kelengkapan informasi seperti pengertian banjir, penyebab banjir, dan solusi yang bisa dilakukan untuk mengurangi banjir, serta dampak penyakit yang bisa disebabkan oleh banjir.

Penggunaan kosakata yang menarik, jelas, dan tepat membuat informasi yang disampaikan menjadi salah satu nilai ketertarikan pembaca dalam menikmati hasil tulisan siswa. Pembendaharaan kata yang baru memicu menghasilkan informasi yang baru. Kelogisan dan kesesuaian informasi serta fakta juga menjadikan informasi yang disampaikan menjadi lebih baik. Masih terdapat kesalahan penggunaan ejaan pada tulisan siswa, namun kesalahan yang dilakukan secara umum dalam penggunaan huruf kapital. Berdasarkan penjelasan di atas, dapat digambakan ada beberapa aspek yang meningkat dalam menggunakan model VAK (Visual, Auditory, Kinestetik) sebagai berikut.

Tabel 3

Skor Aspek Kemampuan Siswa dalam MenulisTeks Eksposisi Kelas Eksperimen

\begin{tabular}{c|c|c|c|c|c|c|c|c|c|c}
\hline $\begin{array}{c}\text { Aspek } \\
\text { yang } \\
\text { dinilai }\end{array}$ & \multicolumn{2}{|l|}{ Struktur } & \multicolumn{3}{|c|}{$\begin{array}{c}\text { Ciri } \\
\text { Kebahasaan }\end{array}$} & \multicolumn{3}{c|}{ Kosakata } & \multicolumn{3}{c}{ Mekanik } \\
\hline Skor & 30 & 20 & 30 & 20 & 20 & 15 & 10 & 20 & 15 & 10 \\
\hline $\begin{array}{c}\text { Jumlah } \\
\text { siswa }\end{array}$ & 19 & 11 & 18 & 12 & 16 & 8 & 6 & 10 & 13 & 7 \\
\hline
\end{tabular}

Berdasarkan tabel di atas terlihat bahwa pemahaman siswa mengenai struktur, ciri kebahasaan, kosakata dan mekanik termasuk dalam kategori baik. Hal ini disebabkan oleh tindakan yang dilakukan dalam proses pembelajaran yang menggunakan tampilan video dan gambar pembelajaran mengenai banjir, yang meningkatkan kemampuan siswa dalam menemukan kata kunci penting dalam peristiwa banjir. 


\section{Kemampuan menulis teks eksposisi dengan menggunakan model}

cooperative learning oleh siswa kelas X SMK Sandhy Putra 2 Medan Tahun Pembelajaran 2018/2019

Pada penggunaan model cooperative learning ini siswa kurang memahami aspek-aspek yang harus diperhatikan dalam indikator menulis teks eksposisi, baik yang berhubungan dengan struktur teks, ciri kebahasaan, penggunaan kosakata, dan mekanik. Rendahnya hasil belajar siswa dalam menulis teks eksposisi ini disebabkan siswa masih berlatih dengan menggunakan model pembelajaran yang menuntut menyatukan pendapat di dalam sebuah kerja kelompok sehingga dapat memecahkan permasalahan yang dihadapi. Siswa hanya menuliskan informasi yang didapatkan dari hasil tukar pikir antar teman sekelompoknya tanpa adanya pengembangan kosakata, sehingga pengembangan kosakata yang dimiliki masih rendah. Penggunaan kosakata yang masih umum tanpa adanya pengembangan dan penjelasan hal ini terlihat pada tulisan siswa "Penyebab banjir kedua terjadinya banjir karena jika menebang atau membakar hutan dapat menghabiskan pohon atau lahan hijau”. Hal ini terlihat bahwa penjelasan penyebab banjir masih dijelaskan secara umum dan masih terlihat penggunaan konjungsi yang berlebihan.

Struktur teks eksposisi terdiri dari tiga yaitu terdapat tesis, argumentasi, dan penegasan ulang (rekomendasi). Secara umum siswa mampu membuat tesis dan argumentasi, sedangkan pada penegasan ulang (rekomendasi) siswa masih memiliki kesulitan dalam membuat sebuah kesimpulan mengenai permasalahan yang dipaparkan. Hal ini disebabkan oleh kurangnya kemampuan siswa dalam mengembangkan kosakata. Seperti yang terlihat pada tulisan siswa “...selain sistem drainase yg buruk. Banjir berawal dari hujan lebat yg berlangsung yg sejak sore...", akibat penggunaan kosakata yang kurang tepat dan jelas dapat menyebabkan kohesi dan koherensi antar kalimat menjadi berkurang.

Kosakata yang digunakan siswa dalam menulis cenderung jelas namun tidak menarik karena monoton menggunakan kalimat yang umumnya diketahui oleh semua orang misalnya, penebangan pohon, tidak 
membuang sampah pada tempatnya. Tidak ada pembendaharaan kosakata yang baru yang digunakan dalam memaparkan suatu permasalahan.

Begitu halnya dengan mekanik, siswa diharapkan mampu menggunakan ejaan bahasa Indonesia yang baik dan benar. Akan tetapi, siswa masih saja melakukan kesalahan dalam penulisan, misalnya saja penggunaan singkatan seperti "yg". Penggunaan huruf kapital yang tidak sesuai, misalnya mengggunakan huruf kapital tidak sesuai dengan ejaan, misalnya "...selain karena Curah hujan yang tinggi...”, "banjir adalah peristiwa yang terjadi...".Berdasarkan penjelasan di atas, dapat digambakan ada beberapa aspek yang meningkat dalam menggunakan model cooperative learning sebagai berikut.

Tabel 4

Skor Aspek Kemampuan Siswa dalam MenulisTeks Eksposisi Kelas Kontrol

\begin{tabular}{|c|c|c|c|c|c|c|c|c|c|c|c|c|c|c|}
\hline $\begin{array}{c}\text { Aspek } \\
\text { yang } \\
\text { dinilai }\end{array}$ & \multicolumn{3}{|c|}{ Struktur } & \multicolumn{5}{|c|}{ Ciri Kebahasaan } & \multicolumn{3}{|c|}{ Kosakata } & \multicolumn{3}{|c|}{ Mekanik } \\
\hline Skor & 30 & 20 & 10 & 30 & 20 & 15 & 10 & 5 & 20 & 15 & 10 & 15 & 10 & 5 \\
\hline $\begin{array}{r}\text { Jumlah } \\
\text { Siswa }\end{array}$ & 15 & 12 & 3 & 1 & 5 & 17 & 6 & 1 & 1 & 19 & 10 & 8 & 20 & 2 \\
\hline
\end{tabular}

Berdasarkan tabel di atas terlihat bahwa pemahaman siswa mengenai struktur, ciri kebahasaan, kosakata dan mekanik termasuk dalam kategori cukup. Hal ini dikarenakan jumlah siswa yang mendapatkan nilai tertinggi lebih sedikit dibandingkan dengan nilai yang rendah.

\section{Pengaruh model pembelajaran VAK (Visual, Auditory, Kinestetik)} terhadap kemampuan menulis teks eksposisi siswa kelas X SMK Sandhy Putra 2 Medan Tahun Pembelajaran 2018/2019

Hasil penelitian yang menunjukkan nilai rata-rata untuk kemampuan menulis teks eksposisi siswa pada kelas kontrol dengan menggunakan model cooperative learning tergolong pada kategori cukup dengan nilai rata-rata adalah 63.16, dibandingkan dengan kemampuan menulis teks eksposisi siswa pada kelas eksperimen dengan menggunakan model VAK (Visual, Auditory, Kinestetik) tergolong pada kategori baik dengan nilai 
rata-rata 84.5. Sehingga dari data tersebut disimpulkan bahwa model pembelajaran VAK (Visual, Auditory, Kinestetik) berpengaruh dalam kemampuan menulis teks eksposisi.

Tabel 5

Perbandingan Skor Kelas Eksperimen dan Kelas Kontrol

\begin{tabular}{c|l|l|l|l|l}
\hline \multirow{2}{*}{ Kelas } & \multicolumn{5}{c}{ Aspek yang dinilai } \\
\cline { 2 - 6 } & & Struktur & $\begin{array}{l}\text { Ciri } \\
\text { Kebahasaan }\end{array}$ & Kosakata & Mekanik \\
\hline \multirow{3}{*}{ Eksperimen } & $\begin{array}{l}\text { Jumlah } \\
\text { Skor }\end{array}$ & 790 & 780 & 500 & 465 \\
\cline { 2 - 6 } & Rata-rata & 26.3 & 26 & 16.67 & 15.5 \\
\hline \multirow{5}{*}{ Kontrol } & $\begin{array}{l}\text { Jumlah } \\
\text { Skor }\end{array}$ & 720 & 450 & 405 & 330 \\
\cline { 2 - 7 } & Rata-rata & 24 & 15 & 13.5 & 11 \\
\hline
\end{tabular}

perolehan skor pada kelas eksperimen pada setiap aspeknya lebih tinggi

dibandingkan dengan kelas kontrol yang mendapatkan nilai yang lebih rendah.

\section{PENUTUP}

Hasil data rata-rata kemampuan menulis dengan menggunakan model VAK (Visual, Auditory, Kinestetik) ditemukan hasil rata-rata secara keseluruhan 84.5 dan tergolong pada kategori baik. Hal ini terlihat dari kemampuan siswa dalam menguasai struktur, ciri kebahasaan dan penggunaan kosakata yang beragam dalam menulis. Siswa lebih aktif dan antusias dalam belajar, hal ini dikarenakan adanya penggunaan beberapa video dan media gambar yang digunakan dalam proses belajar mengajar. Berdasarkan hal tersebut terlihat bahwa kemampuan siswa dalam menulis struktur teks eksposisi (tesis, argumentasi, dan penegasan ulang) dapat dikatakan baik hal ini terlihat dari jumlah siswa yang mendapatkan nilai tertinggi berjumlah 19 siswa, ciri kebahasaan (persuasif, fakta, mengomentari, konjungsi, teknis, dan mental) siswa yang mendapatkan nilai tertinggi berjumlah 18 orang, dan penggunaan kosakata yang berjumlah 16 orang.

Hasil data rata-rata kemampuan menulis teks eksposisi dengan menggunakan model cooperative learningyaitu sebesar 63.16 dan tergolong pada 
kategori cukup. Hal ini berdasarkan kurangnya pemahaman siswa mengenai ciri kebahasaan yang menyebabkan pengembangan kosakata yang tetap monoton sehingga jarang ditemukan kosakata yang baru dalam tulisan.

Model VAK (Visual, Auditory, Kinestetik) lebih berpengaruh secara signifikan dibandingkan dengan model cooperative learningterhadap kemampuan menulis teks eksposisi siswa kelas X SMK Sandhy Putra 2 Medan tahun pembelajaran 2018/2019. Hal ini berdasarkan kemampuan siswa yang semakin meningkat dikarenakan adanya beberapa perubahan yang dilakukan dalam kegiatan belajar mengajar sehingga memacu minat dan motivasi siswa dalam mengembangkan sebuah informasi sehingga tulisan siswa menjadi tulisan yang bersifat informatif.

Saran yang dapat disampaikan 1) guruhendaknyamengaplikasikanmodelmodel pembelajaran yang bervariasi dan menarik perhatian siswa agar proses belajar mengajar di dalam kelas tidak monoton sehingga siswa dapat memahami pelajaran lebih baik dan dapat menulis teks sesuai dengan kaidahnya.2) Guru hendaknya mampu mengimplementasikan dengan baik model pembelajaran yang digunakan sesuai dengan yang diharapkan dari proses pembelajaran. 3) Peneliti selanjutnya tetap memperhatikan perkembangan model-model pembelajaran yang digunakan di sekolah dalam pembelajaran teks eksposisi dan disarankan untuk peneliti selanjutnya tetap memperhatikan perkembangan siswa dalam menulis agar kemampuan menulis siswa tersebut semakin berkembang.

\section{DAFTAR PUSTAKA}

Fathonah, Siti. 2016. Peningkatan Keterampilan Menulis Puisi Melaui Model VAK pada Siswa Kelas VII B SMP NEGERI 2 Adimulyo Tahun Pembelajaran 2016/2017. Semnasbahtera. Hal. 107-115

Kurnia. 2015. Penerapan Model Problem Based Learning untuk Meningkatkan Kemampuan Menulis Teks Eksposisi pada Siswa Kelas X IIS-4 SMA Negeri 8 Makassar. Jurnal Pepatuzdu. Vol 9 (1). Hal 72-84

Mahsun. 2014. Teks dalam Pembelajaran Bahasa Indonesia Kurikulum 2013. Jakarta: PT RajaGrafindo Persada

Ngalimun. 2014. Strategi dan Model Pembelajaran. Yogyakarta: Aswaja Pressindo 
Setiawan. 2015. Optimalisasi Hasil Belajar Siswa Melalui Penerapan Model Pembelajaran Kooperatif Tipe VAK (Visual, Auditory, Kinestetik). Berkata Ilmiah Pendidikan Fisika. Vol 3(2), hal 87-92

Shoimin, Aris. 2016. 68 Model Pembelajaran Inovatif dalam Kurikulum 2013. Yogyakarta: Ar-Ruzz Media

Sugiyono. 2017. Metode Penelitian Pendidikan: Pendekatan Kuantitatif, Kualitatif, dan $R \& D$. Bandung: Alfabeta 